\title{
OPINI DISCLAIMER: DI MANA AUDITOR INTERNAL? STUDI KASUS KEMENTERIAN KELAUTAN DAN PERIKANAN REPUBLIK INDONESIA
}

\author{
Lita Dharmayuni \\ Jurusan Akuntansi, STIE YAI Jakarta \\ email: litadharmayuni@gmail.com
}

\begin{abstract}
Abstrak
Di Indonesia pengelolaan sektor kelautan dan perikanan diserahkan kepada Kementerian Kelautan dan Perikanan Republik Indonesia (KKP RI). Masyarakat sebagai penyedia dana pembangunan menuntut layanan yang lebih transparan dan lebih baik, sementara sumber daya tumbuh lebih lambat. Hal tersebut menyajikan serangkaian risiko unik untuk sektor publik. Pentingnya audit internal di sektor publik disorot oleh peningkatan fokus dan kebutuhan akan akuntabilitas. Dalam penelitian ini peneliti ingin melihat dimana dan bagaimana peran auditor internal dalam proses penyusunan laporan keuangan sehingga dapat meningkatkan fungsi pengawasan intern yang dapat mencegah terjadinya salah saji dalam penyusunan LKPP. Dalam penelitian ini peneliti juga ingin mengetahui apa saja yang menyebabkan diterbitkannya opini "Auditor Tidak Memberikan Pendapat" atau Disclaimer untuk KKP RI di tahun 2016 dan 2017 tersebut dari sudut pandang para auditor internal. Dari penelitian dapat diketahui bahwa terjadi perubahan role dalam peran auditor internal di KKP RI yang dulunya sebagai watchdog, menjadi helper dan protector saat ini, hal tersebut dilakukan sebagai jawaban atas kebutuhan penciptaan Good Corporate Governance yang lebih baik dan juga untuk memaksimalkan peran auditor internal. Ketidakmampuan memberikan perubahan yang maksimal dikarenakan adanya struktur organisasi yang ada membatasi kewenangan dan peran auditor internal. Kurangnya ketaatan atau kepatuhan dalam pelaksaan rekomendasi audit menyebabkan turunnya kualitas laporan keuangan dan diterbitkannya opini disclaimer untuk LKPP KKP RI di tahun 2016 dan 2017.
\end{abstract}

Kata Kunci: auditor internal, sektor publik, role theory

\section{PENDAHULUAN}

Indonesia merupakan negara kepulauan terbesar kedua di dunia yang memiliki 17.504 pulau dan memiliki garis pantai terpanjang kedua di dunia setelah Kanada, dengan bentang wilayah Indonesia dari ujung barat (Sabang) sampai timur (Merauke) setara dengan jarak London sampai Baghdad, bentang ujung utara (Kep. Satal) dan selatan (P. Rote) setara dengan jarak Jerman hingga Al-Jazair (Dishidros TNI-AL, 1987).

Potensi lestari sumber daya ikan laut Indonesia diperkirakan sebesar 12,54 juta ton per tahun yang tersebar di perairan wilayah Indonesia dan perairan Zona Ekonomi Eksklusif Indonesia (ZEEI) (Komnas Kajiskan, 2016). Dari seluruh potensi sumberdaya ikan tersebut, jumlah tangkapan yang diperbolehkan (JTB) sebesar 10,03 juta ton per tahun atau sekitar 80 persen dari potensi lestari, dan baru dimanfaatkan sebesar 6,42 juta ton pada tahun 2017 atau baru 63,99\% dari JTB, sementara total produksi perikanan tangkap (di laut dan danau) adalah 6,89 juta ton. Potensi mikro flora-fauna kelautan juga belum tereksplorasi sebagai 
penyangga pangan fungsional pada masa depan (KKP RI 2018).

Agar dapat dikelola dengan maksimal, besarnya potensi sektor kelautan di Indonesia tersebut membutuhkan dana anggaran yang cukup besar mengingat cakupan daerah di negara kita yang cukup luas. Di Indonesia pengelolaan sektor kelautan dan perikanan diserahkan kepada Kementerian Kelautan dan Perikanan Republik Indonesia (KKP RI). Dari tahun 2013 hingga 2018 besarnya anggaran pemerintah Indonesia nilainya dapat dilihat di table 1 berikut.

Pengelolaan anggaran negara tersebut dilaporkan dalam laporan keuangan yang disusun oleh KKP RI sebagai salah satu entitas pelaporan sehingga berkewajiban menyelenggarakan akuntansi dan laporan pertanggungjawaban atas pelaksanaan Anggaran Pendapatan dan Belanja Negara dengan menyusun Laporan Keuangan.

Tabel 1 Anggaran KKP RI yang bersumber dari APBN

\begin{tabular}{|l|l|r|}
\hline No & Tahun & Jumlah (Rp) \\
\hline 1. & 2018 & 7.635 .526 .314 .000 \\
\hline 2. & 2017 & 9.138 .167 .255 .000 \\
\hline 3. & 2016 & 10.614 .735 .547 .000 \\
\hline 4. & 2015 & 10.672 .500 .839 .000 \\
\hline 5. & 2014 & 6.170 .120 .707 .000 \\
\hline 6. & 2013 & 7.018 .725 .535 .000 \\
\hline
\end{tabular}

Laporan Keuangan bertujuan umum untuk menyediakan informasi mengenai posisi keuangan entitas pelapor, yang merupakan informasi mengenai sumber daya ekonomi entitas dan klaim terhadap entitas pelapor. Laporan keuangan juga menyediakan informasi mengenai dampak dari transaksi dan peristiwa lainnya yang mengubah sumber daya ekonomik dan klaim entitas. Kedua jenis informasi tersebut menyediakan input yang berguna untuk pengambilan keputusan mengenai penyediaan sumber daya kepada entitas (SAK,2017).

Standar Akuntansi Pemerintah (SAP) menjadi acuan dan pedoman dalam penyusunan Laporan Keuangan Pemerintah Pusat (LKPP) sebagai pengguna Anggaran Negara. LKPP yang disusun oleh Pemerintah Pusat akan memberikan informasi yang diperlukan untuk para stakeholders yang terdiri antara lain adalah wakil rakyat, aparat penegak hukum, pihak-pihak yang memberi pinjaman/donasi/investasi, pemerintah serta rakyat sebagai stakeholders utama (http://www.kemenkeu.go.id).

Di Indonesia akuntansi untuk sektor publik yang disusun oleh pemerintah dituntut untuk melakukan reformasi sama seperti yang dilakukan oleh negara-negara lain sebagai bagian dari implementasi good public governance dalam tujuannya untuk memperbaiki akuntabilitas keuangan sektor public di Indonesia (Susanto, 2015). Salah satu bentuk reformasi yang dilakukan adalah penyusunan dan pengimplementasian SAP berbasis akrual sesuai dengan Peraturan Pemerintah Republik Indonesia Nomor 71 Tahun 2010. Implementasi akuntansi berbasis akrual tersebut dilakukan mulai tahun anggaran 2010 dengan batas toleransi 4 (empat) tahun setelah tahun anggaran 2010.

Informasi yang disajikan dalam laporan keuangan sektor publik bertujuan umum untuk memenuhi kebutuhan informasi dari semua kelompok pengguna. Dengan demikian, laporan keuangan pemerintah tidak dirancang untuk memenuhi kebutuhan spesifik dari masing-masing kelompok pengguna. Namun demikian, berhubung laporan keuangan pemerintah berperan sebagai wujud akuntabilitas pengelolaan keuangan negara, maka komponen laporan yang disajikan setidak-tidaknya mencakup jenis laporan dan elemen informasi yang diharuskan oleh ketentuan peraturan perundang-undangan (statutory reports) (PP No.71 Tahun 2010). 
Dengan semakin majunya teknologi dan berkembangnya media massa, masyarakat menuntut informasi yang lebih transparant dalam banyak hal, tidak terkecuali dalam hal pengelolaan dan pelaporan keuangan negara. Pengelolaan dan pelaporan keuangan negara tersebut dapat dilihat dalam Laporan Keuangan Pemerintah Pusat (LKPP) yang dalam hal ini disusun dan dilaporkan oleh KKP RI sebagai bentuk pertanggung jawaban atas penggunaan uang negara kepada masyarakat.

Laporan Keuangan Pemerintah Pusat terdiri dari Laporan Realisasi Anggaran (LRA), Laporan Perubahan Saldo Anggaran Lebih (LPSAL), Laporan Operasional (LO), Laporan Perubahan Ekuitas (LPE), Neraca, Laporan Arus Kas (LAK) dan Catatan atas Laporan Keuangan (CaLK) (PP Nomor 71, 2010). Tiap jenis Laporan Keuangan tersebut memiliki fungsinya masing-masing dalam memberikan informasi keuangan dari seluruh entitas pada pemerintah pusat. Namun sayangnya informasi tersebut belum banyak dimanfaat oleh para stakeholder, hal tersebut tentu sangat disayangkan dikarenakan pemerintah pusat telah mengupayakan perbaikan mutu dan akuntabilitas LKPP dengan dicapainya opini Wajar Tanpa Pengecualian (WTP) oleh Badan Pemeriksa Keuangan (BPK) sejak tahun 2016. Opini WTP berarti Laporan Keuangan telah terbebas dari salah saji yang bersifat material dan telah disajikan sesuai dengan Standar Akuntansi Pemerintahan (SAP). Dengan kata lain berarti angka dan data yang tersaji pada LKPP mempunyai tingkat akurasi yang cukup dan dapat dipertanggungjawabkan kebenarannya (http://www.kemenkeu.go.id).

\section{KAJIAN LITERATUR}

\section{Kementerian Kelautan dan Perikanan Republik Indonesia}

Pada tanggal 26 Oktober 1999 Presiden Abdurrahman Wahid dengan Keputusan Presiden No.355/M Tahun 1999 dalam Kabinet Periode 1999-2004 mengangkat Ir. Sarwono Kusumaatmaja sebagai Menteri Eksplorasi Laut. Selanjutnya pengangkatan tersebut diikuti dengan pembentukan Departemen Eksplorasi Laut (DEL) beserta rincian tugas dan fungsinya melalui Keputusan Presiden Nomor 136 Tahun 1999 tanggal 10 November 1999 tentang Kedudukan, Tugas, Fungsi, Susunan Organisasi, dan Tata Kerja Departemen.

Ternyata penggunaan nomenklatur DEL tidak berlangsung lama karena berdasarkan usulan DPR dan berbagai pihak, telah dilakukan perubahan penyebutan dari Menteri Eksplorasi Laut menjadi Menteri Eksplorasi Laut dan Perikanan berdasarkan Keputusan Presiden Nomor 145 Tahun 1999 tanggal 1 Desember 1999. Perubahan ini ditindaklanjuti dengan penggantian nomenklatur DEL menjadi Departemen Eksplorasi Laut dan Perikanan (DELP) melalui Keputusan Presiden Nomor 147 Tahun 1999 tanggal 1 Desember 1999.

Dalam perkembangan selanjutnya, telah terjadi perombakan susunan kabinet setelah Sidang Tahunan MPR tahun 2000, dan terjadi perubahan nomenklatur DELP menjadi Departemen Kelautan dan Perikanan (DKP) sesuai Keputusan Presiden Nomor 165 Tahun 2000 tanggal 23 November 2000 tentang Kedudukan, Tugas, Fungsi, Wewenang, Susunan Organisasi, dan Tata Kerja Departemen. Kemudian berubah menjadi Kementrian Kelautan dan Perikanan sesuai dengan Peraturan Presiden No. 47 tahun 2009 tentang Pembentukan dan Organisasi Kementerian Negara, maka Nomenklatur Departemen Kelautan dan Perikanan menjadi Kementerian Kelautan dan Perikanan, sedangkan struktur organisasi 
pada Kementerian Kelautan dan Perikanan tidak mengalami perubahan. Dalam rangka menindaklanjuti Keputusan Presiden Nomor 165 Tahun 2000 tersebut, pada November 2000 telah dilakukan penyempurnaan organisasi DKP. Pada akhir tahun 2000, diterbitkan Keputusan Presiden Nomor 177 Tahun 2000 tentang Susunan Organisasi dan Tugas Departemen, dimana organisasi DKP yang baru menjadi:

1. Menteri Kelautan dan Perikanan;

2. Sekretaris Jenderal;

3. Direktorat Jenderal Perikanan Tangkap;

4. Direktorat Jenderal Perikanan Budidaya;

5. Direktorat Jenderal Pengendalian Sumberdaya Kelautan dan Perikanan;

6. Direktorat Jenderal Peningkatan Kapasitas Kelembagaan dan Pemasaran;

7. Direktorat Jenderal Pesisir dan Pulaupulau Kecil;

8. Inspektorat Jenderal;

9. Badan Riset Kelautan dan Perikanan;

10. Staf Ahli (https://kkp.go.id/page/6-sejarah).

Di Kementerian Kelautan dan Perikanan, fungsi pengawasan internal dilakukan oleh Inspektorat Jenderal, sesuai Peraturan Menteri Kelautan dan Perikanan Nomor 6/PERMENKP/2017 tentang Organisasi dan Tata Kerja Kementerian Kelautan dan Perikanan, maka: Inspektorat Jenderal mempunyai tugas melaksanakan pengawasan intern di lingkungan Kementerian Kelautan dan Perikanan yang menyelenggarakan fungsi:

1. Penyusunan kebijakan teknis pengawasan intern di lingkungan KKP $\mathrm{RI}$;

2. Pelaksanaan pengawasan intern di lingkungan KKP RI terhadap kinerja dan keuangan melalui audit, reviu, evaluasi, pemantauan, dan kegiatan pengawasan lainnya;

3. Pelaksanaan pengawasan untuk tujuan tertentu atas penugasan Menteri;

4. Penyusunan laporan hasil pengawasan di lingkungan KKP RI

5. Pelaksanaan administrasi Inspektorat Jenderal; dan

6. Pelaksanaan fungsi lain yang diberikan oleh Menteri (https://kkp.go.id/itjen/page/25-tugasdan-fungsi).

\section{Auditor Internal dan Opini Audit atas Laporan Keuangan KKP RI}

Tidak ada negara yang dapat berfungsi secara tertib tanpa pemerintah yang efektif. Warga suatu negara tidak dapat memenuhi semua kebutuhan mereka dalam kapasitas individu dan bergantung pada pemerintah mereka untuk banyak kebutuhan infrastruktur dasar (Rensburg.J.O.J \& Coetzee.P, 2016).

Untuk memperoleh manfaat maksimal atas penggunaan uang negara KKP RI sebagai salah satu Lembaga Negara yang bertugas untuk melaksanakan pembangunan sektor kelautan dan perikanan harus dapat merencanakan dan melaksanakan program dan rencana kegiatan yang telah disusun sejak awal. Masyarakat sebagai penyedia dana pembangunan menuntut layanan yang lebih transparan dan lebih baik, sementara sumber daya tumbuh lebih lambat. Hal tersebut menyajikan serangkaian risiko unik untuk sektor publik. Pentingnya audit internal di sektor publik disorot oleh peningkatan fokus dan kebutuhan akan akuntabilitas (Asare, 2009: 23; Aikins, 2011: 307-309)

Pengawasan intern adalah seluruh proses kegiatan audit, reviu, evaluasi, pemantauan, dan kegiatan pengawasan lain terhadap penyelenggaraan tugas dan fungsi organisasi dalam rangka memberikan keyakinan yang memadai bahwa kegiatan telah dilaksanakan sesuai 
dengan tolok ukur yang telah ditetapkan secara efektif dan efisien untuk kepentingan pimpinan dalam mewujudkan tata kelolala kepemerintahan yang baik (Permen PAN \& Reformasi Birokrasi No.19 Tahun 2009).

Pentingnya audit internal di sektor publik saat ini menjadi perhatian masyarakat karena adanya kebutuhan akan akuntabilitas (Asare, 2009: 23; Aikins, 2011). Audit internal dilakukan sebagai bentuk pengawasan internal untuk memastikan bahwa pengelolaan dan pelaksanaan pembangunan akan memberi dampak maksimal pada kesejahteraan masyarakat. Dalam prakteknya audit dan pengawasan internal pada sektor publik tidak sama dengan sektor swasta, hal tersebut dikarenakan organisasi sektor publik tidak memiliki kinerja dan akuntabilitas internal yang sama dengan sektor swasta.

Dari 91 (Sembilan puluh satu) Laporan Keuangan Kementerian/Lembaga (LKKL) dan Laporan Keuangan Bendahara Umum Negara (LKBUN) di tahun anggaran 2018 KKP RI merupakan satu-satunya Kementerian Pusat yang memiliki hasil audit yang tidak stabil dari tahun 2009 menurut Badan Pemeriksa Keuangan (BPK) sebagai auditor eksternal untuk Kementerian/Lembaga.

Tabel 3 Hasil Opini BPK atas Laporan Keuangan KKP RI

\begin{tabular}{|c|c|}
\hline Tahun & Opini BPK \\
\hline 2009 & Wajar Dengan Pengecualian \\
\hline 2010 & $\begin{array}{l}\text { Wajar Tanpa Pengecualian- } \\
\text { Dengan Paragraf Penjelasan }\end{array}$ \\
\hline 2011 & $\begin{array}{l}\text { Wajar Tanpa Pengecualian- } \\
\text { Dengan Paragraf Penjelasan }\end{array}$ \\
\hline 2012 & $\begin{array}{l}\text { Wajar Tanpa Pengecualian- } \\
\text { Dengan Paragraf Penjelasan }\end{array}$ \\
\hline 2013 & $\begin{array}{l}\text { Wajar Tanpa Pengecualian- } \\
\text { Dengan Paragraf Penjelasan }\end{array}$ \\
\hline 2014 & $\begin{array}{l}\text { Wajar Tanpa Pengecualian- } \\
\text { Dengan Paragraf Penjelasan }\end{array}$ \\
\hline 2015 & Wajar Tanpa Pengecualian \\
\hline
\end{tabular}

\begin{tabular}{|c|c|}
\hline 2016 & Auditor Tidak Memberikan \\
\hline & $\begin{array}{l}\text { Pendapat } \\
\text { Auditor Tidak Memberikan }\end{array}$ \\
\hline & $\begin{array}{l}\text { Pendapat } \\
\text { Wajar Tanpa Pengecualian }\end{array}$ \\
\hline
\end{tabular}
sumber : bpk.go.id

Dari informasi tersebut dapat terlihat bahwa menurut BPK kualitas laporan keuangan yang disusun tidak menghasilkan mutu, informasi dan akuntabilitas yang sama dari tahun ke tahun. Opini audit "Auditor Tidak Memberikan Pendapat" atau Disclaimer yang diberikan oleh BPK kepada KKP RI tentu saja mengerankan dikarenakan dimasing-masing Kementerian tidak terkecuali KKP RI memiliki internal auditor yang diharapkan dapat menjadi pihak yang diandalkan dalam penyusunan laporan keuangan setiap tahunnya.

Manajemen keuangan yang akuntabel dan transparan adalah tujuan penting dari reformasi akuntansi dan administrasi di sektor publik. Untuk memastikan bahwa manajemen keuangan telah akuntabel dan transparan, fungsi akuntabilitas dan audit pelaporan keuangan sektor publik harus dilaksanakan dengan benar (Asmara, 2017).

Auditor internal dalam upaya pencapaian posisinya untuk dikenali melakukan fungsi ganda lewat compliance dengan menjadi penjaga dan menunjukkan performa dengan berperan sebagai penolong dan pelindung (Ferry, 2017). Hal tersebut sejalan dengan (Roussy, 2013) yang menyatakan bahwa auditor internal melakukan dua peran kunci: protector role dan helper role. Kedua fungsi tersebut diharapkan dapat memaksimalkan peran internal auditor dalam melakukan fungsinya sebagai pengawasan internal.

Dalam penelitian ini peneliti ingin melihat dimana dan bagaiman peran auditor internal dalam proses penyusunan laporan keuangan sehingga dapat meningkatkan fungsi pengawasan intern 
yang dapat mencegah terjadinya salah saji dalam penyusunan LKPP. Dalam penelitian ini peneliti juga ingin mengetahui apa saja yang menyebabkan diterbitkannya opini "Auditor Tidak Memberikan Pendapat" atau Disclaimer untuk KKP RI di tahun 2016 dan 2017 tersebut dari sudut pandang para auditor internal.

\section{METODE PENELITIAN}

Dalam penelitian ini penulis akan membahas peran pengawasan intern yang dilakukan oleh auditor internal dengan menggunakan role theory seperti yang dikemukakan oleh Katz and Kahn (1966). Secara umum role behaviour atau perilaku suatu role (peran) mengacu pada tindakan saat ini dari seorang individu, yang secara tepat saling berhubungan dengan aktivitas yang sering berulang-ulang yang diberikan oleh orang atau pihak lain sehingga menghasilkan outcome (hasil) yang dapat diperkirakan. Sifat atau tindakan yang saling bergantung terdiri dari social system atau subsystem, yaitu suatu pola yang stabil dimana setiap orang menjalankan perannya masing-masing. Dalam organisasi yang sifatnya formal peran yang dijalankan oleh masingmasing orang lebih kepada bagaimana fungsi mereka dalam pengaturan sosial daripada bagaimana karakter mereka sebagai seorang individu (Katz and Kahn, 1966).

Role theory dalam organisasi didasarkan atas role sending dan role receiving yang didasarkan atas empat konsep yaitu :
1. Role expectation, yang merupakan evaluative standards yang diterapkan kepada behaviour seseorang yang menduduki jabatan atau posisi dalam organisasi.

2. Sent role, yang terdiri dari komunikasi yang berasal dari role expectation dan sent (dikirimkan) oleh member of the role set sebagai usaha untuk mempengaruhi focal person.

3. Received role, merupakan focal person's perception atas role-sendings yang diberikan kepadanya, termasuk role yang dikirimkan untuk dirinya sendiri.

4. Role behaviour, merupakan respon dari focal person atas informasi yang komplek dan pengaruh yang telah diterimanya.

Proses dimana expectation dari suatu member of a role set dikaitkan dengan behaviour dari focal person untuk orang tersebut dijelaskan dalam istilah role episodes. Role episode terdiri dari urutan peristiwa yang melibatkan member of a role dan focal person. Proses dimulai saat timbul role expectation yang diharapkan oleh member of the set untuk focal person; yang terdiri dari kegiatan atau tugas yang diharapkan diselesaikan oleh focal person, dengan harapan focal

person dapat melaksanakan tugasnya atau untuk mendapatkan kepuasan mereka sendiri. Langkah berikutnya adalah menyampaikan role expectation tersebut kepada focal person, komunikasi dari role requirements tersebut dilakukan untuk mempengaruhi behaviour dari focal person tersebut (Katz and Kahn, 1966). Hubungan tersebut dapat terlihat dengan jelas pada figure 1 di bawah ini. 


\begin{tabular}{|c|c|c|c|}
\hline \multicolumn{2}{|c|}{ Role Senders } & \multicolumn{2}{|c|}{ Focal Person } \\
\hline Expectations & Sent Role & Received Role & Role Behaviour \\
\hline $\begin{array}{l}\text { Perseption of } \\
\text { focal person's } \\
\text { behaviour; } \\
\text { evaluation }\end{array}$ & $\begin{array}{l}\text { Information; } \\
\text { attempts at } \\
\text { influence }\end{array}$ & $\begin{array}{l}\text { Perception of } \\
\text { role, and } \\
\text { perception of } \\
\text { role sending }\end{array}$ & $\begin{array}{l}\text { Compliance; } \\
\text { resitence; }\end{array}$ \\
\hline
\end{tabular}

Figure 1 Model of the role episode (Katz and Kahn, 1966).

Di samping menggunakan model of the role theory, penelitian ini akan melihat juga role dari auditor intenal lewat role conflict theory seperti yang dikemukakan oleh Katz and Kahn (1966). Menurut role conflict theory kejadian simultan dari dua (atau lebih) pengiriman peran (sent role) yang menyebabkan kepatuhan dengan satu peran akan membuat kepatuhan kepada peran yang lain akan lebih sulit dilakukan. Dalam kasus ekstrim, kepatuhan dengan satu harapan yang dikirim akan mengecualikan kemungkinan kepatuhan dengan yang lain dikarenakan dua harapan itu saling bertentangan.

Dari ke empat role conflict theory seperti yang dikemukakan oleh Katz and Kahn (1966), yaitu intrasender conflict; intersender conflict; interrole conflict dan person-role conflict, pelitian ini akan lebih berfokus kepada intersender conflict untuk melihat role dari intenal auditor di KKP RI. Intersender conflict terjadi saat harapan (role) yang dikirim dari satu pengirim bertentangan dengan harapan (role) dari satu atau lebih pengirim lainnya.

\section{Metodologi Penelitian}

Penelitian ini mengambil data primer dengan menggunakan observasi dan wawancara yang diberikan kepada auditor internal yang terlibat langsung dalam proses pemeriksaan internal. Jumlah keseluruhan auditor internal yang ada di lingkup KKP RI adalah sebanyak 98 orang (kkp.go.id). Karena keterbatasan waktu penelitian, dari seluruh auditor internal tersebut peneliti melakukan observasi dan wawancara kepada 3 (tiga) orang auditor yang memiliki kualifikasi sebagai auditor pertama, auditor muda dan auditor utama. Ketiga kualifikasi tersebut diambil untuk melihat apakah terdapat perbedaan pemahaman akan peran masing-masing auditor tersebut dalam proses pengawasan internal dengan masa kerja dan pengalaman yang berbeda.

Tabel 3. Internal Auditor yang di wawancara

\begin{tabular}{|c|l|c|c|}
\hline No & Jabatan & $\begin{array}{c}\text { Masa } \\
\text { kerja }\end{array}$ & $\begin{array}{c}\text { Durasi } \\
\text { Wawancara }\end{array}$ \\
\hline Auditor 1 & $\begin{array}{l}\text { Auditor } \\
\text { Utama }\end{array}$ & 31 tahun & $+/$-30 menit \\
\hline Auditor 2 & $\begin{array}{l}\text { Auditor } \\
\text { Muda }\end{array}$ & 7 tahun & 59 menit \\
\hline Auditor 3 & $\begin{array}{l}\text { Auditor } \\
\text { Pertama }\end{array}$ & 1 tahun & 38 menit \\
\hline
\end{tabular}

Wawancara yang dilakukan merupakan wawancara semi terstruktur dimana semua auditor diajukan pertanyaan yang sudah disiapkan dan pembicaraan berkembang sesuai kebutuhan. Wawancara dilakukan selama kurang lebih 30 menit hingga 60 menit untuk masing-masing auditor yang diwawancara, dan dilaksanakan di kantor Inspektorat Jenderal 2 KKP RI di Gedung Mina Bahari 3 Jalan Medan Merdeka Timur, Jakarta Pusat.

Hasil wawancara akan di analisis menggunakan role theory yang dikemukanan oleh Katz and Kahn (1966), yang akan dipergunakan untuk menjelaskan peran internal auditor di KKP RI melalui model of the role serta role conflict theory. 


\section{HASIL DAN PEMBAHASAN}

\section{Role expectation}

Role expectation dapat diartikan sebagai standar yang diterapkan kepada behaviour seseorang yang menduduki jabatan atau posisi tertentu dalam organisasi. Sehingga bagaimana seseorang dapat berperan dalam suatu organisasi digambarkan dan diharapkan oleh sistem dan organisasi dibentuk disini.

Di KKP RI auditor internal dalam posisinya sebagai auditor internal di KKP RI diharapkan dapat memenuhi peran sesuai dengan yang diatur dalam Permen PAN \& Reformasi Birokrasi No.19 Tahun 2009 dan Peraturan Menteri Kelautan dan Perikanan Nomor 6/PERMEN-KP/2017, yaitu : seluruh proses kegiatan audit, reviu, evaluasi, pemantauan, dan kegiatan pengawasan lain terhadap penyelenggaraan tugas dan fungsi organisasi dalam rangka memberikan keyakinan yang memadai bahwa kegiatan telah dilaksanakan sesuai dengan tolok ukur yang telah ditetapkan secara efektif dan efisien untuk kepentingan pimpinan dalam mewujudkan tata kelola pemerintahan yang baik.

Dari penjelasan tersebut dapat kita ambil kesimpulan bahwa auditor internal diharapkan dapat mengawasi seluruh proses kegiatan dari perencanaan hingga pelaksanaan program pembangunan yang dilakukan oleh KKP RI sehingga kegiatan tersebut dapat dilakukan secara efektif dan effisien hingga tercapai kesejahteraan masyarakat atau peningkatan welfare bagi warga negara.

Role expectation seperti yang telah disebutkan di atas sangat dipahami oleh semua auditor internal di KKP RI, hal tersebut seperti yang disebutkan oleh salah satu auditor yang menyatakan

"Tugas internal auditor adalah memastikan apa yang dilaksanakan oleh eksekutif dengan menggunakan dana yang berasal dari masyarakat dapat dilaksanakan dengan tepat waktu, tepat sasaran dan tepat jumlah dan memastikan proses pelaksanaannya transparent, akuntabel, jujur dan professional. Auditor 2".

Dari semua auditor yang diwawancara juga memberikan jawaban dan pemahaman yang tidak jauh berbeda, mengingat semua auditor di KKP RI merasa berkewajiban untuk bekerja sesuai dengan Permen PAN \& Reformasi Birokrasi No.19 Tahun 2009 dan Peraturan Menteri Kelautan dan Perikanan Nomor 6/PERMEN-KP/2017.

\section{Sent role}

Adalah bagian yang terdiri dari komunikasi yang berasal dari role expectation dan sent (dikirimkan) oleh member of the role set sebagai usaha untuk mempengaruhi focal person. Dimana tahap ini akan menentukan bagaimana pemahaman focal person dalam hal ini internal auditor di KKP RI membentuk pemahamannya tentang tugas dan wewenangnya.

Dalam KKP RI sent role dilakukan dengan membuat aturan yang dapat menjelaskan bagaimana kegiatan pengawasan dilakukan dan bagaimana auditor internal sebagai pelaksana pengawasan melaksanakan tugasnya. Beberapa aturan yang merupakan sent role antara lain:

1. Peraturan Pemerintah RI Nomor 60 Tahun 2008 tentang Sistem Pengendalian Intern Pemerintah

2. Permen PAN \& Reformasi Birokrasi No.19 Tahun 2009 Pedoman Kendali Mutu Aparat Pengawasan Intern Pemerintah

3. Permen PAN \& Reformasi Birokrasi No.28 Tahun 2012 Pedoman Telaahan Sejawat Hasil Audit Aparat Pengawasan Intern Pemerintah
4. Permen KKP RI Nomor 29/PERMEN-KP/2014 tentang 
Pedoman Pengawasan Intern di Lingkungan KKP RI

5. Permen KKP RI Nomor 6 / PERMEN-KP /2017 Tentang Organisasi dan Tata Kerja Kementerian Kelautan dan Perikanan.

6. Peraturan Inspektorat Jenderal Kementerian Kelautan dan Perikanan Nomor 52.18.1/PER-IRJEN/ 2013 tentang Pedoman Pengawasan lingkup Inspektorat Jenderal Kementerian Kelautan dan Perikanan

7. Peraturan Inspektur Jenderal Kementerian Kelautan dan Perikanan Nomor 07.12.9/ PER-IRJEN/ 2015 tentang Rencana Strategis Inspektorat Jenderal Kementerian Kelautan dan Perikanan

8. Peraturan Inspektur Jenderal Kementerian Kelautan dan Perikanan Nomor 229.11.1/ PER-IRJEN/ 2015 tentang Pedoman Telaah Sejawat Hasil Pengawasan Aparat Pengawasan Intern Pemerintah di Lingkup Inspektorat Jenderal Kementerian Kelautan dan Perikanan

9. Peraturan Inspektur Jenderal Kementerian Kelautan dan Perikanan Nomor 192.4.1/ PER-IRJEN/ 2016 tentang Kode Etik Pegawai Inspektorat jenderal Kementerian Kelautan dan Perikanan

10. Keputusan Dewan Pengurus Nasional Asosiasi Auditor Intern Pemerintah Indonesia Nomor KEP005/AAIPII/DPN/2014 tentag Pemberlakuan Kode Etik Auditor Intern Pemerintah Indonesia, Standar Audit Intern Pemerintah Indonesia, dan Pedoman Telaah Sejawat Auditor Intern Pemerintah Indonesia.

Menurut (Hay. D \& Cordery. C, 2018) auditor sektor publik memiliki tanggung jawab untuk melakukan audit terkait value of money serta audit laporan keuangan, dimana auditor internal harus dapat menilai apakah uang atau dana yang dikeluarkan oleh pemerintah dalam melaksanakan kegiatan dan tugasnya sudah sesuai nilai dan manfaatnya untuk masyarakat dan hal tersebut sudah terwakili oleh sent role yang telah ditetapkan untuk auditor internal di KKP RI.

Dari berbagai aturan yang ditetapkan tersebut dapat kita lihat bahwa sent role yang diberikan kepada auditor internal telah cukup lengkap dan komprehensif dengan memberikan role terkait bagaimana, apa yang ingin dicapai lewat pengawasan yang dilakukan oleh auditor internal, lingkup pekerjaan, aturan yang dipakai, kode etik yang diinginkan dicapai dan review dengan rekan sejawat.

\section{Received role}

Dalam tahap received role yang merupakan tahap dimana focal person's perception atau persepsi auditor internal terhadap role-sendings yang diberikan kepadanya dipahami oleh masing-masing auditor internal, termasuk didalamnya adalah role yang dikirimkan dan dipahami untuk masing-masing auditor.

Lewat wawancara yang dilakukan diketahui bahwa semua auditor internal memiliki pemahaman yang cukup mengenai sent role yang dikirimkan kepada masing-masing auditor internal.

"Kami bekerja berdasarkan aturan sesuai yang ditetapkan pemerintah, itu menjadi pedoman dan panduan dalam melaksanakan pekerjaan pengawasaan, pemeriksaan dan pelaporan. Auditor 2".

Masing-masing auditor sangat menyadari bahwa peran mereka lebih sebagai helper dan protector lebih dari peran sebagai watchdog, dimana internal auditor diharapkan sebagai quality assurance, yang dapat mendampingi dari awal dilakukannya program pemerintah yang dimuali dari proses perencanaan, pelaksanaan hingga pelaporan sudah dilakukan dengan benar dan telah 
mempertimbangkan dampak maksimal terhadap kemakmuran masyarakat.

"Program kerja yang dilakukan terpenuhi sehingga memberi dampak welfare kepada masyarakat. Auditor 1".

Di sekitar tahun 1960an hingga 1990an di masa orde baru peran auditor internal lebih kepada watchdog. Namun saat ini peran sebagai watchdog sudah dirasakan tidak relevan lagi, dikarenakan pola pemerintahan dan aturan yang mengatur cara kerja auditor internal juga telah mengalami perubahan yang disesuaikan dengan perkembangan sektor public.

"Dulu jika kita masuk seperti mencaricari kesalahan, inspektor jenderal ditakuti karena dianggap jika ada pemeriksaan pasti karena ada kesalahan. Sekarang sudah tidak bisa lagi seperti itu. Kita lebih senang disebut helper dan protectors. Auditor 1".

\section{Role behaviour}

Role behaviour dapat dijelaskan sebagai respon dari auditor internal atas informasi yang komplek dan pengaruh yang telah diterimanya. Informasi dan pengaruh tersebut membentuk persepsi auditor internal akan tugas dan kewajibannya dan bagaimana auditor internal tersebut merespon informasi yang diterimanya untuk meningkatkan kualitas dirinya.

Di KKP RI auditor internal diharapkan memiliki sifat profesionalisme dengan melaksanakan pelatihan untuk penjenjangan dan persyaratan keahlian.

"Setelah di rekrut menjadi pegawai dengan berbagai disiplin ilmu, para auditor internal tersebut harus melewati pelatihan untuk meningkatkan kompetensi. Perekrutan pegawai dengan berbagai disiplin keilmuan dikarenakan mitra kerja auditor memiliki berbagai macam program kegiatan, contoh misalnya pembangunan fisik, kualifikasi auditor internal yang dibutuhkan adalah teknik sipil dan arsitek. Auditor 2".
Kompetensi yang dilakukan tersebut diharapkan dapat meningkatkan kualitas kerja dari auditor internal.

"Pekerjaan yang berkualitas jika dilakukan sesuai aturan yang berlaku, tepat waktu, lengkap, dan rekomendasi yang diberikan dilaksanakan oleh pihak yang diberikan rekomendasi. Auditor 1".

Untuk memastikan pekerjaan pengawasan yang dilakukan mampu untuk berkembang dalam hal kualitas kerja, auditor internal di KKP RI telah menerapkan IA-CM model. Tujuan utama dari model ini adalah untuk memberikan penilaian mandiri dan alat peningkatan berkelanjutan agar dapat berkembang secara mandiri untuk sektor publik (Rensburg. J. O J \& Coetzee. P, 2016).

"Kami ada standar IA-CM (Internal Audit Capability Model) yang ditetapkan BPKP sebagai standar Internal Auditor di KKP RI. Auditor 3".

\section{Role conflict theory.}

Seperti yang telah dijelaskan di atas, di tahun 2016 dan 2017, KKP RI mendapatkan opini disclaimer terhadap laporan keuangannya, saat ditanyakan dimana peran auditor internal dalam posisinya sebagai protector untuk mencegah hal tersebut terjadi mengungkapkan bahwa adanya keterbatasan kewenangan membuat para auditor internal tidak bisa berbuat banyak.

"Ada kondisi di mana kami sudah menginfokan, jika ada hal yang meragukan, tolong dikonsultasikan, ada beberapa kejadian dimana pejabat yang bertanggung jawab atas program kerja tertentu tidak melakukan konsultasi, ada juga dimana pejabat tersebut berkonsultasi tetapi tidak melakukan rekomendasi seperti yang telah disarankan. Auditor 2".

"Itu masalah politik di atas, saya tidak mengetahui dengan jelas. Auditor 3".

"Kita bekerja personal dengan kaedah audit dan standar baik aturan dan etika yang telah ditetapkan, seringkali 
rekomendasi yang diberikan kepada pejabat tertentu dijanjikan akan dikerjakan tetapi lalai ada juga rekomendasi tersebut tidak dikerjakan. Singkatnya adanya ketidakpedulian. Dan setiap kali dilakukan pemeriksaan telah diingatkan tetapi tidak diindahkan, bisa jadi dikarenakan ada hal yang ditutupi. Auditor 1".

Internal auditor dalam melakukan rolenya sebagai helper dan protector pada akhirnya terbatas dikarenakan struktur organisasi yang mengharuskan internal auditor di KKP untuk bekerja dibawah struktur organisasi tertentu. Hal tersebut sejalan dengan role conflict theory seperti yang dijelaskan oleh Katz and Kahn (1966) dimana sent role yang diterima dan dipahami oleh masing-masing focal person dalam hal ini auditor internal di KKP RI bertentangan dengan harapan (role) sebagai staf atau bawahan secara organisasi.

Para auditor internal yang meyakini bahwa hasil perkerjaan mereka dalam bentuk rekomendasi harus segera diikuti dalam prakteknya mengalami pertentangan dengan posisinya secara struktural yang seringkali jenjang kepangkatan dan masa kerjanya berada dibawah atau setara dengan bagian yang diawasi. Keadaan tersebut menyulitkan auditor internal di KKP RI untuk bisa memastikan bahwa hasil rekondasi tersebut akan dilakukan tepat waktu dan sesuai dengan yang disarankan sehingga peran auditor internal sebagai helper dan protector tidak terlaksana dengan maksimal. Hal tersebut sesuai dengan penelitian Novriansa. A \& Riyanto. B (2016) yang menyatakan posisi auditor internal pemerintah daerah, yang sama dengan atau di bawah bagian yang diawasi, dapat menyulitkan auditor internal pemerintah daerah untuk menjadi independen karena posisi ini memberi mereka kontrol terbatas ketika melakukan pemeriksaan dan menindaklanjuti hasil pemeriksaan.

\section{SIMPULAN}

Dari penelitian dapat diketahui bahwa terjadi perubahan role dalam peran auditor internal di KKP RI yang dulunya sebagai watchdog, menjadi helper dan protector saat ini, hal tersebut dilakukan sebagai jawaban atas kebutuhan penciptaan Good Corporate Governance yang lebih baik dan juga untuk memaksimalkan peran auditor internal sehingga pengawasan dan pendampingan dapat dilakukan dengan lebih baik.

Para auditor internal KKP RI akan bekerja sesuai aturan yang telah ditetapkan dan kode etik yang berlaku, agar tercapai output pemeriksaan yang berkualitas dan hasil rekomendasi yang bermanfaat untuk meyakinkan kegiatan pembangunan yang dilakukan akan semaksimal mungkin dapat meningkatkan kesejahteraan masyarakat.

Ketidakmampuan memberikan perubahan yang maksimal dikarenakan adanya struktur organisasi yang ada membatasi kewenangan dan peran auditor internal. Kurangnya ketaatan atau kepatuhan dalam pelaksaan rekomendasi audit menyebabkan turunnya kualitas laporan keuangan dan diterbitkannya opini disclaimer untuk LKPP KKP RI di tahun 2016 dan 2017.

Penelitian ini diharapkan dapat memberikan gambaran yang lebih jelas akan peran auditor internal di public sector dengan lebih aktual, dan memberikan pemahaman bagaimana auditor internal di public sector secara umum berbeda dengan auditor internal di private sector. Kedepan diharapkan penelitian lain dapat dilakukan untuk konteks lembaga pemerintahan (kementerian) yang lain, terutama kementerian yang mendapatkan opini audit WTP secara terus menerus, untuk 
dapat melihat bagaimana peran auditor internal yang dapat memaksimalkan fungsi pengawasannya agar tercipta laporan keuangan yang bermutu tinggi.

Seperti penelitian lain, penelitian ini juga memiliki keterbatasan, antara lain, wawancara hanya dilakukan dari sisi auditor internal saja, sehingga pemahaman dari pihak lain seperti penyusun laporan keuangan dan pejabat terkait yang lain sangat disarankan untuk dapat memberikan pemahaman dan informasi dari sudut pandang yang berbeda.

\section{REFERENSI}

Aikins SK. 2011. An Examination of Government Internal Audits' Role in Improving Financial Performance. Public Finance and Management 11(4): 306-337.

Asare T. 2009. Internal Auditing in the Public Sector: Promoting Good Governance and Performance Improvement. International Journal on Governmental Financial Management 9(1): 15-28.

Asmara. R. Y (2017). The Effects of Internal Auditors Competence and Independence on

Ferry, L., Zakaria, Z., Zakaria, Z., \& Slack, R. (2017). Watchdogs, helpers or protectors? - Internal auditing in Malaysian Local Government. Accounting Forum.

Katz D, Kahn RL. The social psychology of organizations. New York: John Wiley and Sons; 1966.

Kementerian Kelautan dan Perikanan Republik Indonesia. Sejarah. https://kkp.go.id/page/6-sejarah

Kementerian Kelautan dan Perikanan Republik Indonesia (2011). Peraturan Menteri Kelautan dan Perikanan tentang sistem akuntansi dan pelaporan keuangan di lingkungan
Kementerian Kelautan dan Perikanan Nomor 19 Tahun 2011.

Kementerian Kelautan dan Perikanan Republik Indonesia (2018). Laporan Tahunan 2018.

Kementerian Keuangan Republik Indonesia (2010). Standar Akuntansi Pemerintahan. Peraturan Pemerintah Indonesia Nomor 71 tahun 2010.

Kementerian Keuangan Republik Indonesia (2017). Memanfaatkan laporan keuangan pemerintah pusat sebagai sumber rujukan menilai kinerja pemerintah. http://www.kemenkeu.go.id

KSAP. (2010). SAP: Kerangka konseptual akuntansi pemerintahan. Jakarta: Komite Standar Akuntansi Pemerintahan.

Nogueira, Sonia. P. S \& Jorge, Susana. M. F. (2016). Explanatory factors for the use of the financial report in decisionmaking: Evidence from local government in Portugal. Spanish Accounting Review 19 (2) 216-226.

Novriansa. A \& Riyanto. B. (2016). Role conflict and role ambiguity on local government internal auditors: the determinant and impacts. Journal of Indonesian Economy and Business Volume 31, Number 1, 63 -82.

Rensburg. J. O J \& Coetzee. P (2016). Internal audit public sector capability: a case study. Journal of Public Affairs. Volume 16 Number 2 pp 181-191.

Roussy.M. (2013). Internal auditors' roles: From watchdogs to helpers and protectors of the top manager. Critical Perspectives on Accounting. 